\title{
Structural Characteristics and Hydration Kinetics of Oxidized Steel Slag in a $\mathrm{CaO}-\mathrm{FeO}-\mathrm{SiO}_{2}-\mathrm{MgO}$ System
}

https://doi.org/10.1515/htmp-2017-0163

Received November 02, 2017; accepted July 30, 2018

Abstract: Although steel slag exhibits cementitious properties, the addition of steel slag in cement is still limited due to both the presence of excess iron oxides and instability of free lime and periclase. This paper proposes a method for oxidizing molten slag in air, aiming at extraction of superfluous wustite and stabilization of free lime and periclase. Mineralogical characteristics of raw slag and modified products were examined using X-ray diffraction (XRD), scanning electron microscopy equipped with backscattered electron imaging (SEM-BEI), energy dispersive spectrometry (EDS) and thermogravimetric analysis (TGA) with differential scanning calorimetry (DSC). Thermodynamic calculations were performed to aid to discuss the experimental results. The results indicate that non-magnetic wustite and periclase are transformed into magnetic spinel (magnetite/ magnesioferrite) after oxidation. Temperature has a significant effect on the formation of spinel. The mass fraction of free lime decreases from $3.54 \mathrm{wt} . \%$ to $0.96 \mathrm{wt} . \%$ as a result of the conversion from free lime to calcium ferrite.

\footnotetext{
*Corresponding author: Yuhong Chen, School of Material Science and Engineering, North Minzu University, Yinchuan 750021, China, E-mail: lyhchen@163.com

Liang Jiang, School of Material Science and Engineering, North Minzu University, Yinchuan 750021, China; Key State Laboratory of Green Building Materials, China Building Material Academy, Beijing 100024, China, E-mail: jiangliang@nun.edu.cn

Yiwang Bao, Key State Laboratory of Green Building Materials, China Building Material Academy, Beijing 100024, China, E-mail: ywbao@ctc.ac.cn

Guiqun Liu: E-mail: gqliu10b@alum.imr.ac.cn, Xiaoli Zhang: E-mail: 282300562@qq.com, Fenglan Han:

E-mail: hanfenglan@hotmail.com, School of Material Science and Engineering, North Minzu University, Yinchuan 750021, China Qixing Yang, Department of Civil, Minerals and Metallurgical Engineering, Environmental and Natural Resources Engineering, Luleå University of Technology, Luleå SE-971 87, Sweden, E-mail: qixing.yang@ltu.se
}

Keywords: steel slag, wustite, magnetite, spinel, oxidation PACS $^{\circledR}$ (2010). 82.60.Lf

\section{Introduction}

Steelmaking slag, which is produced when molten steel is separated from impurities, is a by-product of the steelmaking industry. The amount of this slag is approximately $12-20 \%$ of the steel yield. Dumping of the slag occupies large areas and always results in serious environmental problems, considering that less than $45 \%$ of the steel slag is reused in China [1, 2]. Therefore, technologies for recycling slag are in urgent need [3].

Steel slag, which contains approximately 10-35\% iron and its oxides [4], such as wustite (FeO) [5], magnetite $\left(\mathrm{Fe}_{3} \mathrm{O}_{4}\right)$ and hematite $\left(\mathrm{Fe}_{2} \mathrm{O}_{3}\right)$, can be considered a potential source of metals for use as an iron ore supply. Apart from the potential use of steel slag for iron reduction, the cement industry can also use slag a supplementary material for replacing part of raw materials. The dicalcium ferrite $\left(\mathrm{C}_{2} \mathrm{~F}\right)$, tetracalcium aluminoferrite $\left(\mathrm{C}_{4} \mathrm{AF}\right)$, tricalcium silicate $\left(\mathrm{C}_{3} \mathrm{~S}\right)$ and dicalcium silicate $\left(\mathrm{C}_{2} \mathrm{~S}\right)$ in slag are beneficial to the cement industry $[6,7]$, whereas free lime (f- $\mathrm{CaO}$ ), periclase $(\mathrm{MgO})$ and excess wustite are unfavorable. The presence of free lime and periclase leads to highly problematic swelling; meanwhile excess amounts of wustite damage the mechanical properties of slag cement. Because the mass fraction of wustite in most Chinese steel slag is too high for utilization as cement, considerable work has been conducted on this topic $[3,8]$. The iron that is present in steel slag can be recovered using many approaches, such as oxidation of the molten slag by $\mathrm{CO}_{2}$ gas [9], carbon reduction $[10,11]$ and magnetic separation $[12,13]$. However, the first two methods require substantial energy and are not ecofriendly, and the latter is inapplicable for nonmagnetic substances [14]. A sustainable approach for separating superfluous wustite in slag was proposed by Zhang etal. and Semykina etal. [15-18]. This approach consists of transforming the non-magnetic 
wustite into magnetic magnetite by oxidation, followed by magnetic separation of the magnetic part. Zhang et al. presented the oxidation mechanism of $\mathrm{CaO}-\mathrm{SiO}_{2}-$ $\mathrm{FeO}_{x}$ slag with high iron content in a pure oxygen atmosphere [15]. Studies on the $\mathrm{CaO}-\mathrm{SiO}_{2}-\mathrm{FeO}$ and $\mathrm{CaO}-\mathrm{SiO}_{2}$ $\mathrm{FeO}-\mathrm{MnO}$ systems, followed by kinetic modeling and thermodynamic calculations, were performed by Semykina etal. [16-18]. However, considering that Chinese steel industry steel slag contains 5-8wt.\% $\mathrm{MgO}$ in most cases [19], these studies did not place much emphasis on the oxidation of steel slag in a quaternary $\mathrm{CaO}-\mathrm{FeO}-\mathrm{SiO}_{2}-\mathrm{MgO}$ system, and the stabilization treatments of free lime and periclase during the oxidation process were not mentioned.

In addition to the extraction of iron and iron oxides from steel slag, many approaches have also been reported for enhancing the properties of slag, such as chemical [20], thermal [21, 22] or mechanical methods [23], aiming at better utilization of steel slag in the cement field. However, these techniques are defined as "back-end modification approaches", where additional chemical activators and energy are essential, and the modification leads to varieties of minerals and chemical compositions of slag [24].

Herein, considering the above reasons, we focus on the oxidation of molten slag, explore a method for converting superfluous wustite in steel slag, and attempt to utilize stabilization treatments of free lime and free periclase [25, 26]. Industrial slag was utilized as the modifying material, and a quaternary $\mathrm{CaO}-\mathrm{FeO}-\mathrm{SiO}_{2}-\mathrm{MgO}$ system was considered as the modifying system. Thermodynamics calculations of the oxidative modification were conducted using FactSage 6.4 to aid the discussion of the experimental results.

\section{Experimental}

\section{Materials}

The steel slag was supplied by the Ning Steel Group (Ningxia, P.R. China), which was generated from the BOF process in the iron and steel factory. This study mainly focuses on the non-magnetic part of the steel slag which are rich in FeO. Pre-magnetic separation was utilized to remove magnetic iron-containing substances like entrapped iron droplets and magnetite, etc. The slag which had been subjected to the following treatments was referred to as the raw slag: homogenized, quartered, milled down to $<0.3 \mathrm{~mm}$ and magnetically separated to reduce the amount of metallic iron.

The chemical compositions of the raw slag are presented in Table 1, which indicates that the raw slag is primarily composed of calcium oxide, iron oxides, magnesia and silica. These results are in good agreement with the literatures [27-29]. The slag is substantially consisted of $\mathrm{CaO}, \mathrm{SiO}_{2}, \mathrm{FeO}$ and $\mathrm{MgO}$. Hence, the slag system should be considered as a $\mathrm{FeO}-\mathrm{CaO}-\mathrm{SiO}_{2}-\mathrm{MgO}$ quaternary system rather than a $\mathrm{FeO}-\mathrm{CaO}-\mathrm{SiO}_{2}$ ternary system.

\section{Processing}

Slag samples, $50 \mathrm{~g}$ in each batch, were placed in an alumina crucible in the furnace (BLMT, Luoyangshi Bolaimante Test Electricity Furnace Co., Ltd, China). The furnace temperature was measured using a $\mathrm{Rh} / \mathrm{Pt}$ thermocouple with an accuracy of $\pm 3^{\circ} \mathrm{C}$. To ensure homogeneity, the slag samples were premelted at $1500^{\circ} \mathrm{C}$ under a purified argon atmosphere, then after an isothermal time of 20 minutes, the samples were cooled to the desired temperatures range (between $1250^{\circ} \mathrm{C}$ and $1350^{\circ} \mathrm{C}$ ) at a preplanned cooling rate $\left(5^{\circ} \mathrm{C} / \mathrm{min}\right)$. After the desired temperature was reached, the atmosphere in the furnace was switched from argon to air, and the latter was injected into the furnace for $30 \mathrm{~min}$ with a flow rate of $7.5 \mathrm{~L} / \mathrm{min}$. The gas mixture was introduced into the reaction zone by an alumina pipe with an inner diameter of $5 \mathrm{~mm}$. After heating, the slag was cooled in the furnace under an argon atmosphere at the maximum possible rate $\left(25^{\circ} \mathrm{C} / \mathrm{min}\right)$.

\section{Analysis}

The compositions of the slag after modification were assessed by X-ray fluorescence spectroscopy (X-ray Fluorescence, Rigaku ZSX-100e). The minerals in the raw slag and in the oxidized products were identified by X-ray diffraction (XRD-6000 Shimadzu, Japan) using $\mathrm{Cu} \mathrm{K}_{\alpha}$ radiation within the $2 \theta$ range of $10-80^{\circ}$ and a scanning step size

Table 1: Chemical analysis of the treated slag (wt.\%).

\begin{tabular}{lccccccrr}
\hline Composition & $\mathrm{CaO}$ & $\mathrm{SiO}_{2}$ & $\mathrm{Fe}_{2} \mathrm{O}_{3}$ & $\mathrm{Fe}$ & $\mathrm{FeO}$ & $\mathrm{MgO}$ & $\mathrm{Al}_{2} \mathrm{O}_{3}$ & $\mathrm{Others}$ \\
\hline Weight percent & 45.50 & 24.01 & 5.27 & 1.27 & 14.76 & 5.53 & 1.59 & 2.07 \\
\hline
\end{tabular}


of $0.02^{\circ}$. The morphological observations of the slag were performed on polished thin specimens using scanning electron microscopy (SSX-550, Shimadzu, Japan) with energy dispersive spectrometry (EDS). The magnetic flux density of the slag was measured using a digital gauss meter (CH-3600, CH-Hall Electronic Devices Inc., China).

The TG-glycol method was developed to determine the free lime content in the slag [30,31].

(1) The mass fraction of total calcium in the slag was measured using the glycol method. Granules of the slag $(2 \mathrm{~g})$ were dissolved in $25 \mathrm{~mL}$ of glycol, and then the mixture was heated in an $80-90^{\circ} \mathrm{C}$ water bath, followed by magnetic stirring for $30 \mathrm{~min}$. Centrifugation was performed to separate the supernatant liquid mixture, to which deionized water, hydrochloric acid, triethanolamine, sodium hydroxide and calcium indicator were added. The color of the solution transformed from red to blue during EDTA titration. The mass fraction of calcium (including free lime and calcium hydroxide) in the slag could be calculated based on the volume of EDTA consumed during the titration.

(2) The slag was heated to the desired temperature $\left(900^{\circ} \mathrm{C}\right.$ ) at a rate of $10^{\circ} \mathrm{C} / \mathrm{min}$ under flowing purified argon. The mass fraction of calcium hydroxide in the slag was calculated referring to the loss of water using thermogravimetric analysis (TGA) with differential scanning calorimetry (DSC, NETZSCH Scientific Instruments Trading, Germany) via the TG method. Hereafter, the mass fraction of free lime could be calculated according to eq. (1).

Free lime $(\%)=$ Calcium $(\%)-$ Calcium hydroxide $(\%)$.

The oxidation thermodynamics of the slag were investigated using FactSage 6.4 (Thermofact CRCT Ltd., Montreal,
Canada) with the Fact PS and FToxide databases Heating microscope (LeitzWetzlar, Germany) was employed to evaluate the liquidus temperature of the investigated slag (Figure 1). Fine ground samples were agglomerated into small briquettes ( $2 \mathrm{~mm}$ diameter and $3 \mathrm{~mm}$ height) by using a specified mold. The briquette prepared was placed on a flat alumina pan and introduced into the hot zone of a horizontal tube furnace. Both ends of the furnace were closed with a transparent quartz plug to achieve atmosphere control and imaging. The synthesis air flow was maintained throughout the process. The sample was heated to $600^{\circ} \mathrm{C}$ at $15^{\circ} \mathrm{C} / \mathrm{min}$ and thereafter $10^{\circ} \mathrm{C} / \mathrm{min}$ up to the flow temperature of the sample. The imaging settings are automatically performed according to preset parameters. The dimensional change is monitored by analyzing the profile of the sample and the change in sample size is calculated accordingly. In addition, the hydration of oxidized slag was studied for up to $72 \mathrm{~h}$ at $25 \pm 1{ }^{\circ} \mathrm{C}$ using an isothermal calorimeter (TAM Air, Thermometric AB, Sweden). The specific surface area of the oxidized slag was about $457 \mathrm{~m}^{2} / \mathrm{kg}$.

\section{Results and discussion}

\section{Phase compositions}

\section{Raw slag}

The XRD pattern of the raw slag is presented in Figure 2, which demonstrates that the raw slag is well crystallized because of the sufficient cooling period. The XRD result reveals that $\mathrm{C}_{2} S$ in $\beta$ form is the main phase in the raw slag. It is well known that $C_{2} S$ exists in four well-established polymorphs: $\gamma, \beta, \alpha^{\prime}$ and $\alpha$. During cooling from elevated temperature, $\mathrm{C}_{2} \mathrm{~S}$ in $\alpha$ form converts to $\mathrm{C}_{2} \mathrm{~S}$ in $\beta$ form at approximately $630^{\circ} \mathrm{C}$, then transforms to $y-\mathrm{C}_{2} \mathrm{~S}$ at lower

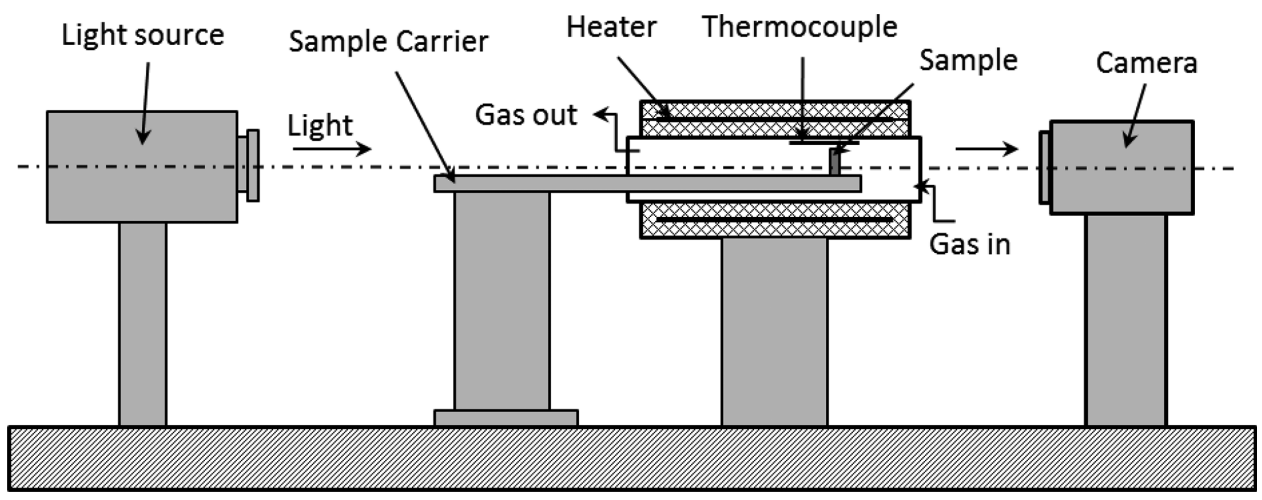

Figure 1: Schematic of heating microscope. 


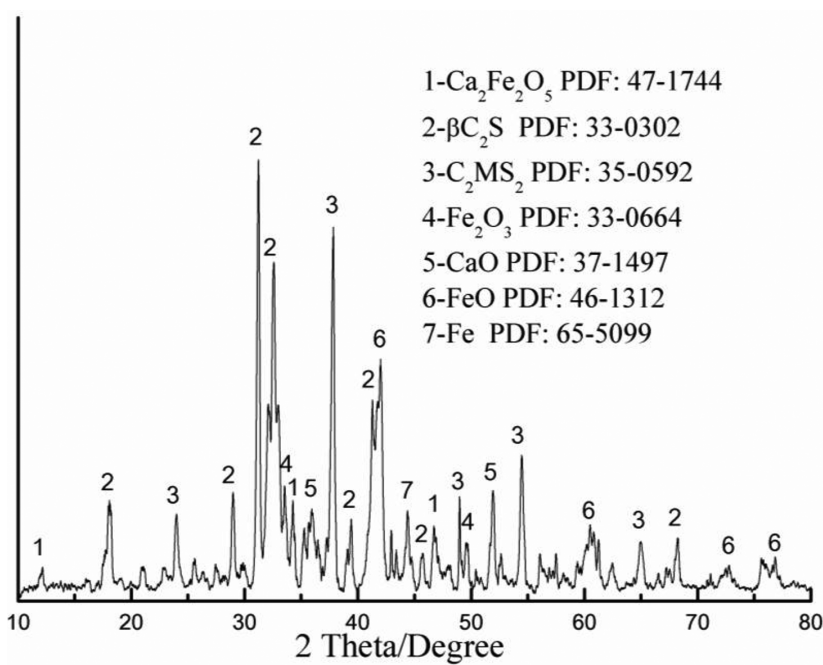

Figure 2: X-ray diffraction analysis of raw sample.

temperature [22]. The conversion of $\beta-\mathrm{C}_{2} \mathrm{~S}$ to $\mathrm{\gamma}-\mathrm{C}_{2} \mathrm{~S}$ is accompanied with an increase in volume and leads to spontaneous disintegration of slag. The presence of metastable $\beta-C_{2} \mathrm{~S}$ in the raw slag is due to the high $\mathrm{FeO}$ content which acts as a stabilizer preventing the disintegration [32]. Iron is distributed in the form of dicalcium ferrite as srebrodolskite, wustite and hematite. Moreover, elemental iron can also be detected. Magnetic separation is almost inapplicable for the raw slag due to the lack of ferromagnetic substances. Note that diffraction peaks corresponding to lime and periclase are present, and the instability of these components is the main reason why raw slag is not appropriate for use in cement.

\section{Modified slag}

The XRD pattern of the modified slag is presented in Figure 3. Dicalcium silicate in $\alpha^{\prime}$ form, dicalcium ferrite, magnetite, hematite and magnesioferrite are identified. The absence of free lime and periclase is highlighted. Compared with the minerals in the raw slag, $\alpha^{\prime}-C_{2} S$ is dominant in the oxidation products. During cooling from elevated temperatures, there is a conversion from $\alpha^{\prime}-C_{2} S$ to $\beta-C_{2} S$ at $725^{\circ} \mathrm{C}$. In contrast, the presence of metastable $\alpha^{\prime}-\mathrm{C}_{2} \mathrm{~S}$ in the oxidized products is attributed to the rapid cooling rate. Temperature appears to have a pronounced influence on the formation of magnetite, magnesioferrite and hematite. The characteristic peak of hematite appears at approximately $1250^{\circ} \mathrm{C}$, accompanied with that of magnetite and magnesioferrite.

In an oxygen-rich condition, wustite can be oxidized to magnetite (Reaction 2), followed by the formation of hematite (Reaction 3 forward). As soon as temperature rising, hematite becomes unstable and begins to dissociate to form magnetite (Reaction 3 backward). Thermal temperature of pure hematite dissociated is at $1350^{\circ} \mathrm{C}$ [33]. However, this temperature is probably affected by the addition of other compositions in the slag system. Blackman investigated the phase diagram of $\mathrm{MgO}-\mathrm{Fe}_{2} \mathrm{O}_{3}$ $\mathrm{MgFe}_{2} \mathrm{O}_{4}$ and found that the mixtures of $\mathrm{Fe}_{2} \mathrm{O}_{3}$ and $\mathrm{MgFe}_{2} \mathrm{O}_{4}$ are considerably dissociated at $1200^{\circ} \mathrm{C}$ and $1300^{\circ} \mathrm{C}$ [34]. According to Phillips $\mathrm{B}$, the transformation temperature from hematite to magnetite slightly decreases followed by adding lime in system [35]. In this investigation, the elevated temperature facilitates

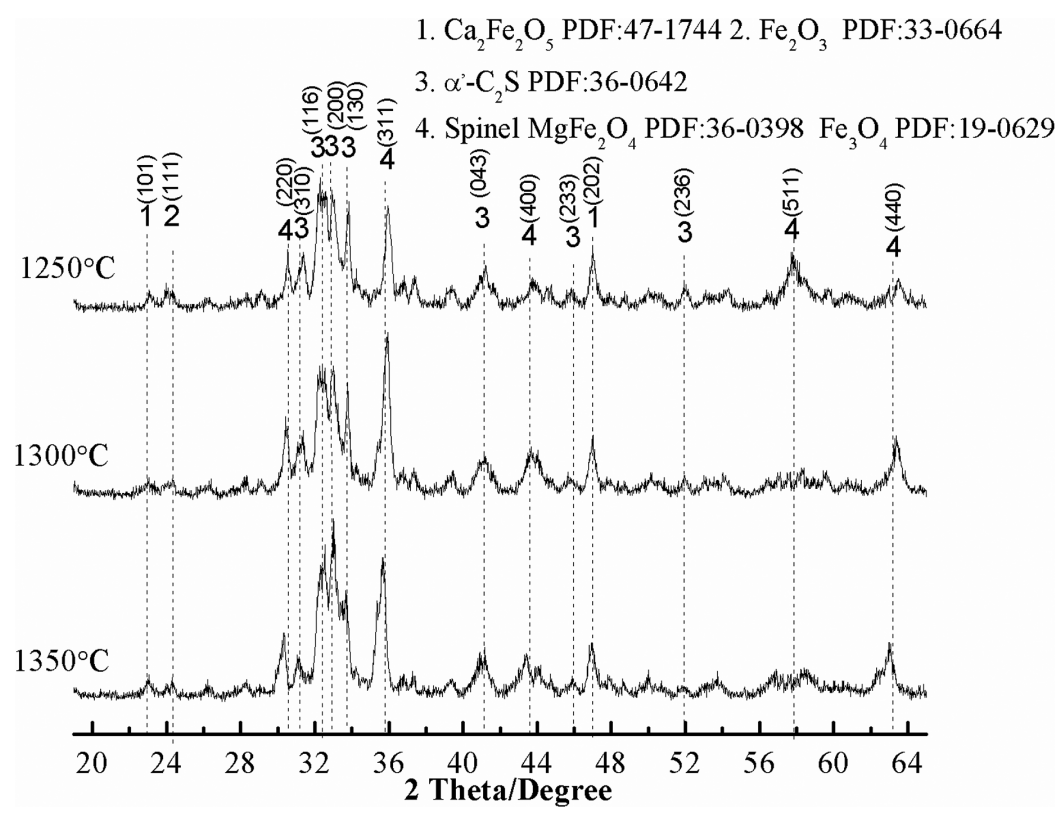

Figure 3: X-ray diffraction analysis of the oxidized slag at different temperatures. 
the transformation of hematite to magnetite, resulting in the absence of hematite at temperature above $1300^{\circ} \mathrm{C}$.

$$
\begin{aligned}
3 \mathrm{FeO}+1 / 2 \mathrm{O}_{2} & =\mathrm{Fe}_{3} \mathrm{O}_{4} \\
2 \mathrm{Fe}_{3} \mathrm{O}_{4}+1 / 2 \mathrm{O}_{2} & \rightleftharpoons 3 \mathrm{Fe}_{2} \mathrm{O}_{3}
\end{aligned}
$$

The formation of magnesioferrite depends on addition of $\mathrm{MgO}$ and elevated temperature. According to Yadav [36] and Xue [37], $\mathrm{MgO}$ has a more positive role in restraining the formation of $\mathrm{Fe}_{2} \mathrm{O}_{3}$ and promoting the formation of $(\mathrm{Mg}, \mathrm{Fe}) \mathrm{Fe}_{2} \mathrm{O}_{4}$ in low basic slag. Shu also believed that the addition of $\mathrm{MgO}$ not only induce the precipitation of $\mathrm{MgFe}_{2} \mathrm{O}_{4}$ spinel but also promote the crystallization of steel slag [38]. As the heating temperature reaches $1000^{\circ} \mathrm{C}$, $\mathrm{Mg}^{2+}$ replaces some of $\mathrm{Fe}^{2+}$ from the magnetite lattice by solid state diffusion, forming mixed spinels [36, 39]. Both of magnetite $\left(\mathrm{Fe}^{3+}\left(\mathrm{Fe}^{2+} \mathrm{Fe}^{3+}\right) \mathrm{O}_{4}\right)$ and magnesioferrite $\left(\mathrm{Fe}^{3+}\left(\mathrm{Mg}^{2+} \mathrm{Fe}^{3+}\right) \mathrm{O}_{4}\right)$ have inverse spinel structure and show magnetic properties. There is no obviously differences in crystal structure between magnetite and magnesioferrite, thus it is difficult to distinguish magnetite and magnesioferrite by means of X-ray diffraction. The intensities of the diffraction peaks corresponding to magnetite and magnesioferrite increase between $1250^{\circ} \mathrm{C}$ and $1300^{\circ} \mathrm{C}$ and then slightly decrease at $1350^{\circ} \mathrm{C}$.

\section{Microstructures}

Backscattered SEM with EDS was conducted to investigate the microstructures of the modified slag. To further analyze the nature and characteristics of the oxidized slag, the nature of transverse and longitudinal sections of the oxidized product at $1300^{\circ} \mathrm{C}$ are shown in Figure 4.

In the transverse section of the oxidized slag (Figure 4(a)), three domains are observed: a large amount of a white domain with an average grain size of $1-4 \mu \mathrm{m}$, the distribution of which is scattered. The EDS analysis (Marked 1) reveals that this domain is primarily composed of $\mathrm{Mg}, \mathrm{Fe}$ and $\mathrm{O}$ elements (Table 2), and the Fe:Mg:O ratio is approximately 3.9:1:8.5. The ionic radii of the $\mathrm{Fe}^{2+}$ ion and of $\mathrm{Mg}^{2+}$ ion are similar in size, which are 0.078 and $0.083 \mathrm{~nm}$, respectively. Hence, the $\mathrm{Fe}^{2+}$ ions in magnetite could easily be replaced by $\mathrm{Mg}^{2+}$ ions, resulting in the formation of a substitutional solid solution (magnesioferrite) [40], which indicates that the white domain is primarily composed of magnetite and magnesioferrite phases. Magnesioferrite exhibits an inverse spinel structure, in which eight $\mathrm{Fe}^{3+}$ ions are in tetrahedral interstices and eight $\mathrm{Fe}^{3+}$ along with eight $\mathrm{Mg}^{2+}$ ions are in octahedral sites [41]. As mentioned early, both magnetite and magnesioferrite are ferromagnetic substances, and they are the main components of the spinel phase. The crystallization of magnesioferrite in the slag tends to attach to magnetite; thus, they are optically indistinguishable from each other [36]. Moreover, the XRD results reveal the conversion from wustite and periclase to magnetite and magnesioferrite, resulting in a significant decrease of free periclase in the slag.

The dark gray domain in the SEM images of the slag has a grain size of $2-6 \mu \mathrm{m}$. The EDS analysis (Marked 2) indicates that $\mathrm{Ca}$ and $\mathrm{O}$ are the major constituents of the dark gray domain, with $\mathrm{Fe}$ and $\mathrm{Mg}$ as minor elements. The $\mathrm{Ca}: \mathrm{Fe}: \mathrm{Al}: \mathrm{O}$ ratio is approximately 1.2:0.9:0.2:3.9, which indicates that the dark gray domain is mainly composed of dicalcium ferrite with a small amount of Al. Some $\mathrm{Fe}^{3+}$ ions are potentially replaced by $\mathrm{Al}^{3+}$ ions in dicalcium ferrite, leading to the formation of calcium aluminoferrite $\left(\mathrm{Ca}_{2}\left(\mathrm{Fe}, \mathrm{Al}_{2} \mathrm{O}_{5}\right)\right.$ as srebrodolskite type [42].

The light gray domain observed in the SEM image is well crystallized with a grain size of $8-16 \mu \mathrm{m}$. The EDS
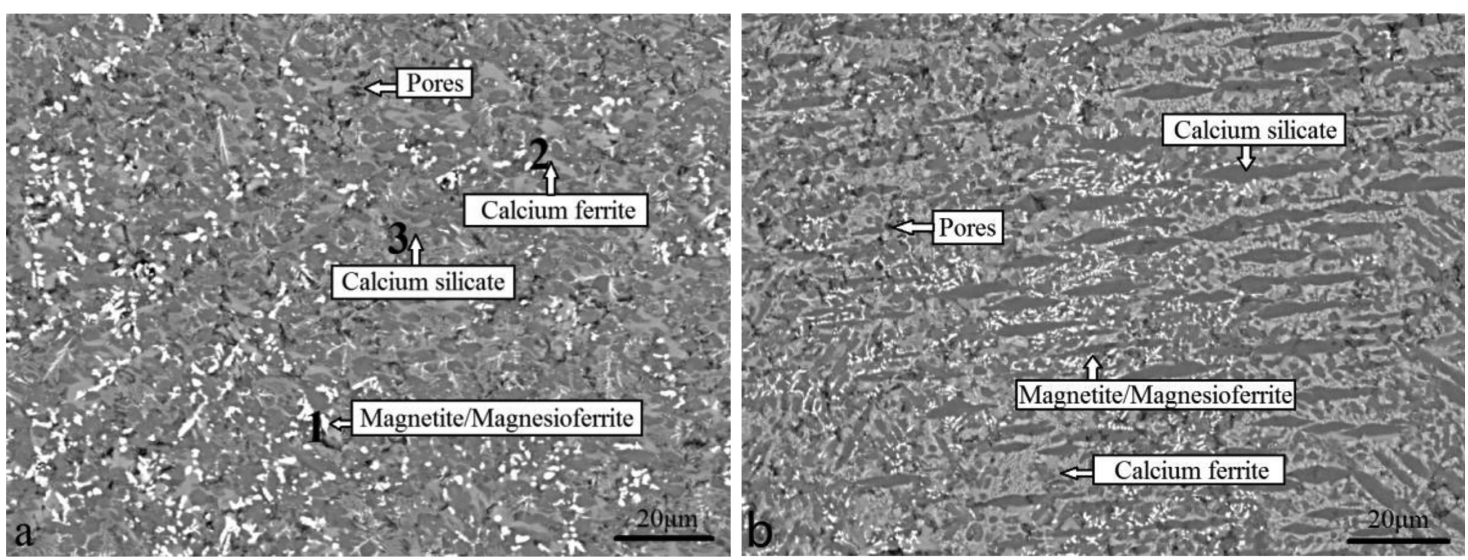

Figure 4: SEM-BEl images for the samples oxidized at $1300^{\circ} \mathrm{C}$ : (a) transverse section; (b) longitudinal section. 
Table 2: EDS results of the modified samples, corresponding to Figure 4.

\begin{tabular}{lrlrlr}
\hline $\begin{array}{l}\text { Marked 1 } \\
\text { element }\end{array}$ & Atomic\% & $\begin{array}{l}\text { Marked } \\
\text { element 2 }\end{array}$ & $\begin{array}{r}\text { Atomic\% } \\
\text { element 3 }\end{array}$ & $\begin{array}{r}\text { Marked } \\
\text { \% }\end{array}$ \\
\hline O & 59.09 & $\mathrm{O}$ & 59.13 & $\mathrm{O}$ & 49.39 \\
$\mathrm{Mg}$ & 6.94 & $\mathrm{Mg}$ & 1.32 & $\mathrm{Mg}$ & 2.24 \\
$\mathrm{Al}$ & 1.11 & $\mathrm{Al}$ & $3.63 \mathrm{Al}$ & 1.12 \\
$\mathrm{Si}$ & $0.99 \mathrm{Si}$ & $2.19 \mathrm{Si}$ & 13.95 \\
$\mathrm{Ca}$ & $3.84 \mathrm{Ca}$ & $18.46 \mathrm{Ca}$ & 26.00 \\
$\mathrm{Ti}$ & $0.13 \mathrm{Ti}$ & $0.29 \mathrm{Ti}$ & 0.50 \\
$\mathrm{Cr}$ & $0.12 \mathrm{Cr}$ & $0.12 \mathrm{Cr}$ & 0.27 \\
$\mathrm{Mn}$ & 0.95 & $\mathrm{Mn}$ & 0.89 & $\mathrm{Mn}$ & 0.85 \\
Fe & 26.83 & $\mathrm{Fe}$ & 13.97 & $\mathrm{Fe}$ & 5.68 \\
Total & 100.00 & $\mathrm{Total}$ & 100.00 & Total & 100.00 \\
\hline
\end{tabular}

analysis (Marked 3) indicates that the light gray domain mainly contains $\mathrm{Ca}, \mathrm{Si}, \mathrm{Fe}$ and $\mathrm{O}$, and the $n_{\mathrm{CaO}} / n_{\mathrm{SiO} 2}$ ratio is approximately 1.9. Combined with the XRD results, it can be inferred that the light gray domain is composed of dicalcium silicate with a small amount of merwinite.

In the longitudinal section of the oxidized slag (Figure 4(b)), the presence of dicalcium ferrite, calcium silicate, magnesioferrite, magnetite and pores is also observed. Calcium silicate is observed to have a grain size of $15-40 \mu \mathrm{m}$ in the longitudinal section. The compositions of modified slag analyzed by XRF are shown in Table 3. A slightly increase in the contents of $\mathrm{Al}_{2} \mathrm{O}_{3}$ and trace amounts of $\mathrm{Mn}$ are observed, which is potentially due to contamination from the crucible [43].

Table 3: XRF results of the modified samples.

\begin{tabular}{llllllll}
\hline Element & $\mathrm{MgO}$ & $\mathrm{Al}_{2} \mathrm{O}_{3}$ & $\mathrm{SiO}_{2}$ & $\mathrm{CaO}$ & $\mathrm{MnO}$ & $\mathrm{Fe}_{2} \mathrm{O}_{3}$ & Others \\
\hline $\begin{array}{c}\text { Composition } \\
\text { (wt.\%) }\end{array}$ & 5.15 & 2.40 & 22.3 & 42.2 & 0.095 & 26.9 & 0.955 \\
\hline
\end{tabular}

\section{Magnetic measurements}

The amounts of magnetic substances can be evaluated based on the magnetic flux density value, which are listed in Table 4 for the raw slag and the modified products. The value of the magnetic flux density is a vector, where the absolute value and sign indicate the strength and direction of the magnetic field, respectively. The value of the magnetic flux density of the raw sample is so low that it is inapplicable for magnetic separation due to the non-magnetic
Table 4: Magnetic flux density of the samples.

\begin{tabular}{|c|c|c|c|}
\hline $\begin{array}{r}\text { Raw } \\
\text { samples }\end{array}$ & \multicolumn{3}{|c|}{$\begin{array}{r}\text { Modified samples at different } \\
\text { temperature }\left({ }^{\circ} \mathrm{C}\right)\end{array}$} \\
\hline & 1250 & 1300 & 1350 \\
\hline $\begin{array}{l}\text { Magnetic flux density } \\
(\mathrm{mT})\end{array}$ & -0.1194 & -0.3080 & -0.2838 \\
\hline \multicolumn{4}{|c|}{$\begin{array}{l}\text { phases in raw slag (Figure 1). Following oxidation, an } \\
\text { obvious increase in the value of magnetic flux density of } \\
\text { the modified samples implies that there is a significant } \\
\text { transformation from a non-magnetic phase to magnetic } \\
\text { phases. Table } 4 \text { shows that an increase of temperature } \\
\text { from } 1250^{\circ} \mathrm{C} \text { to } 1300^{\circ} \mathrm{C} \text { is followed by an increase in the } \\
\text { magnetic flux density value. Subsequently, the magnetic } \\
\text { flux density value slightly decreases as the temperature } \\
\text { increases from } 1300^{\circ} \mathrm{C} \text { to } 1350^{\circ} \mathrm{C} \text { due to the disintegration } \\
\text { of spinel phases. The results of magnetic measurements are } \\
\text { in agreement with the XRD results. }\end{array}$} \\
\hline
\end{tabular}

\section{Mass fraction of free lime}

Figure 5 presents the TG-DSC curves of the raw slag and the modified slag. The decomposition temperature of calcium hydroxide is between $400^{\circ} \mathrm{C}$ and $550^{\circ} \mathrm{C}$, whereas $\mathrm{C}_{2} \mathrm{~S}, \mathrm{C}_{3} \mathrm{~S}$ and fayalite (CFS) decompose in the temperature range from $550^{\circ} \mathrm{C}$ to $800^{\circ} \mathrm{C}$ [30]. As shown in Figure 5(a), a significant endothermic peak appears in the temperature range from $371.7^{\circ} \mathrm{C}$ to $422.9^{\circ} \mathrm{C}$, which is the decomposition temperature range of calcium hydroxide. Another endothermic peak at approximately $700^{\circ} \mathrm{C}$ is also observed in Figure 5(a), which is caused by the partial decomposition of $\mathrm{C}_{2} \mathrm{~S}$ according to the XRD results of the raw slag. Referring to the calculation using eq. (1), the mass fraction of free lime in the raw slag is 3.54\%. Free lime in raw slag leads to issues for use in the cement industry, and the mass fraction of free lime of $>1.0 \%$ in the slag is unacceptable for cement addition (GB/T213722008, Portland cement clinker).

In the modified slag, there is a transformation from free lime to dicalcium ferrite after oxidation. Dicalcium ferrite, which is extremely stable, is a solid solution that consists of dissolved calcium oxide and hematite. Figure 5(b) presents the TG-DSC curves of the modified slag. The absorption peak corresponding to the decomposition of calcium hydroxide is not observed, which indicates the absence of calcium hydroxide in the modified product. Notably, the TG-DSC curve of the raw slag shows mainly 

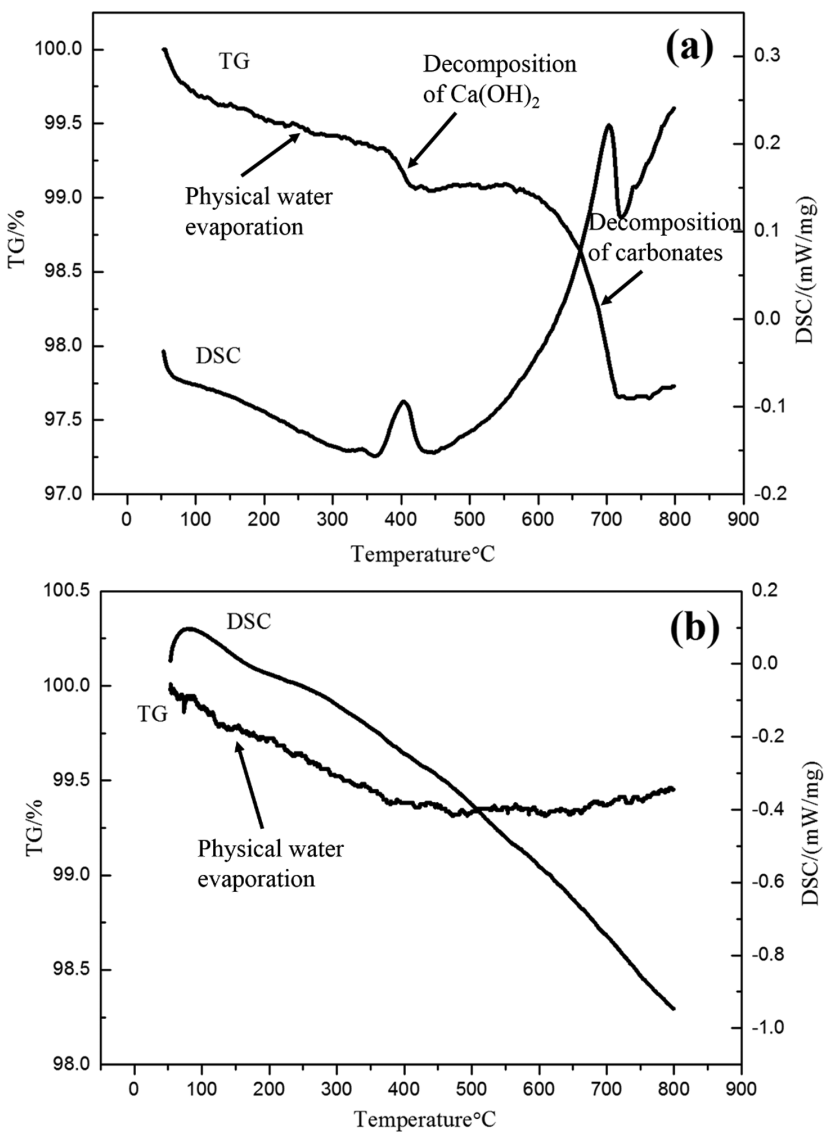

Figure 5: The TG-DSC curves of steel slag samples: (a) raw slag and (b) oxidized slag at $1300^{\circ} \mathrm{C}$.

endothermic events, whereas that of the oxidized product exhibits exothermic events instead. The endothermic characteristic of the raw slag is probably caused by oxidation of the unstable domain during the TG-DSC experimental process. According to the calculation using eq. (1), the mass fraction of free lime in the modified product (Figure 5(b)) is less than $0.96 \%$, which indicates that the modified slag could be utilized as a raw cement material.

\section{Thermodynamics analysis}

Thermodynamics calculations were conducted to further investigate the mineralogical characteristics of the oxidized products and to explain the reaction mechanism of the oxidative transformation in details. Figure 6 presents the results of thermodynamic calculations which are conducted based on the following conditions:

- Temperature interval: $700-1600^{\circ} \mathrm{C}$.

- Pressure: $1 \mathrm{~atm}$, the activities of partial oxygen pressure is 0.21 .

- Solution species: FToxid-SLAGA, FToxid-SPINA, FToxid-MeO-A, FToxid- $\mathrm{bC}_{2} \mathrm{~S}$, FToxid- $\mathrm{aC}_{2} \mathrm{~S}$, FToxidMel.

According to the thermodynamic calculations, as shown in Figure $6, \alpha-\mathrm{C}_{2} \mathrm{~S}$ exhibits a relatively high melting point and precipitates from liquid slag initially. $\mathrm{C}_{2} \mathrm{~S}$ in $\alpha$ form is converted into $\alpha^{\prime}-\mathrm{C}_{2} \mathrm{~S}$ at approximately $1400^{\circ} \mathrm{C}$, followed by the crystallization of spinel (magnetite/magnesioferrite) and dicalcium ferrite. The temperature ranges of spinel occurred are $1100-1400^{\circ} \mathrm{C}$, while the presences of dicalcium ferrite are observed at temperature ranges $1100-1300^{\circ} \mathrm{C}$ and $700-900^{\circ} \mathrm{C}$, respectively. Notably, the

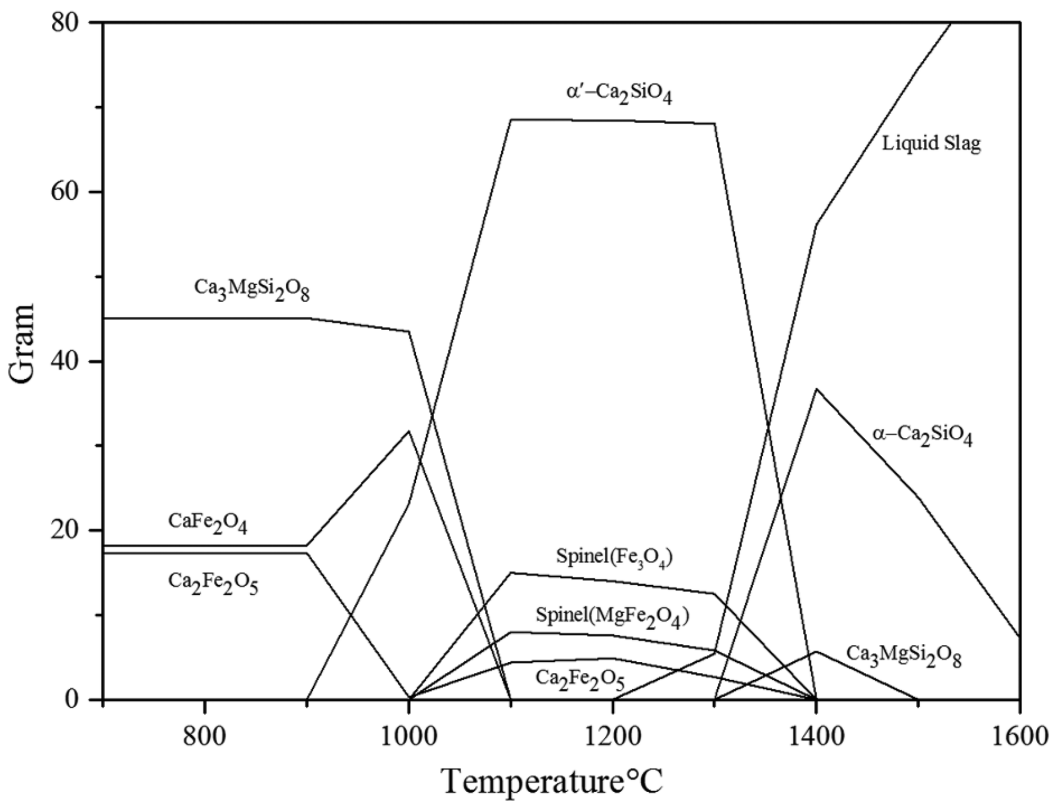

Figure 6: Mass of mineral phases calculated by FactSage 6.4 for oxidized products. 
decreases in spinel contents are always accompanied by the increases in dicalcium ferrite contents at elevated temperatures. Calcium ferrite $\left(\mathrm{CaFe}_{2} \mathrm{O}_{4}\right)$ and merwinite initiate to crystallize below $1100^{\circ} \mathrm{C}$ along with the presence of dicalcium ferrite.

From the thermodynamics predictions, temperature has a significant effect on the mass fractions of the spinel phases. As the temperature increases above $1087^{\circ} \mathrm{C}$ in an oxidizing atmosphere, the formation of spinel occurs in the slag system. However, as the temperature reaches approximately $1273{ }^{\circ} \mathrm{C}$, the mass fraction of spinel begins to decrease due to the formation of the liquid phase, which explains the decrease in spinel contents at temperature above $1350^{\circ} \mathrm{C}$ with respect to the XRD results (Figure 3).

In addition, the powder slag was pressed into small briquettes and then heated in synthesis air to continue imaging to capture swelling, deformation and melting phenomena. The silhouette sample area changed as a function of temperature is shown in Figure 7. The sample shade alteration as the temperature increases are shown on the right hand side of Figure 7 . The image (a) displays briquette at ambient temperature, and the images (b), (c) and (d) are for deformed briquette, hemisphere deformed sample and completely melted sample, respectively [44]. The relationship between temperature and the change of silhouette sample area is manifested on the left side. No swelling is detected before $1239^{\circ} \mathrm{C}$. As the heating temperature rises, the briquette shows gradual swelling followed by melting above $1338^{\circ} \mathrm{C}$. The experimental liquidus temperature is higher than theoretically liquidus temperature calculated using FactSage 6.4, because a small amount of elements in the steel slag such as Mn, Al, et al., is not included in the thermodynamic prediction.

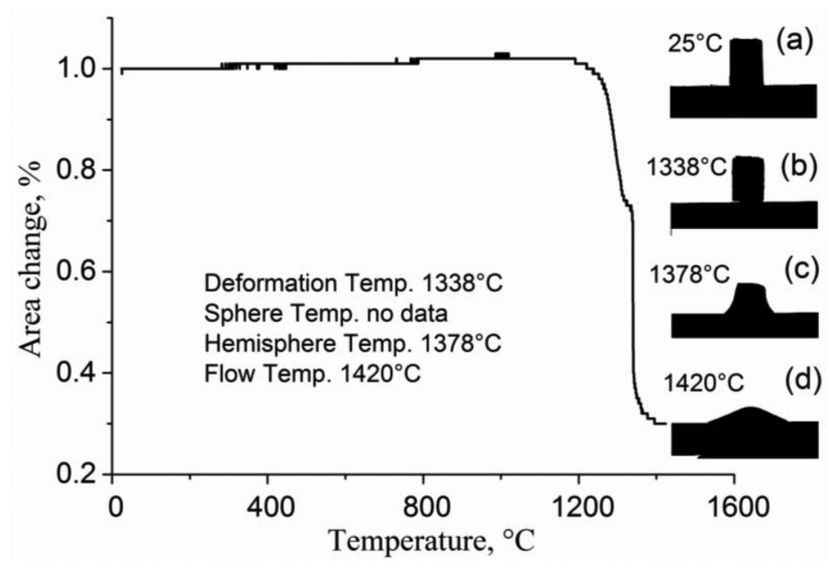

Figure 7: Selected images show the investigated slag deformation and swelling.
The emphasis of the oxidation process is placed on obtaining spinel and avoiding the formation of hematite, for which the oxidation temperature exerts a significant influence. Murphy et al. suggested that lime in the slag prefers to combine with silica to generate tricalcium silicate and dicalcium silicate; then, residual lime combines with iron oxide to produce a dicalcium ferrite phase or calcium aluminoferrite phase [45]. The thermodynamic calculations also demonstrate that in the slag system, dicalcium silicate is generated first, and then dicalcium ferrite occurs, followed by the formation of magnetite and magnesioferrite.

\section{Oxidation mechanism}

The oxidation process of steel slag could be simply considered as the following steps (Figure 8), which has been proved in our previous investigation [25]:

(1) Initial stage

The initial step is occurred as the oxidant gas let in. At this period, the oxygen molecules begin to impinge on the slag surface leading to the oxidation of wustite in the slag. This procedure is usually carried out rapidly during whole oxidizing process [16].

(2) Chemical reaction

At this period, magnetite and magnesioferrite begin to form via the combination of divalent iron, magnesium and oxygen atoms. The layer of spinel appears in the surface and becomes thick gradually followed by the increase of the oxidizing time.

(3) Diffusion

In the last stage of the spinel formation, it is difficult to let the divalent iron atom in the bottom to be further oxidized, owing to the increasing thickness of product layer. As the oxidizing duration is more than $40 \mathrm{~min}$, diffusion would dominate the formation of spinel. The ionic radii of oxygen, divalent iron and magnesium are $140 \mathrm{pm}, 76 \mathrm{pm}$ and $65 \mathrm{pm}$, respectively. Due to the relatively large radius, the mobility of the oxygen atom is worse than that of divalent iron atom and magnesium atom.

The mean free path of oxygen molecules can be estimated by the following equation [17]:

$$
\lambda=\frac{\kappa T}{\sqrt{2} \pi P d^{2}},
$$

where $\lambda$ is the mean free path of the oxygen molecule; $P$ is the pressure; $d$ is the diameter of the oxygen molecule; $\kappa$ is the Boltzmann constant; and $T$ is the 


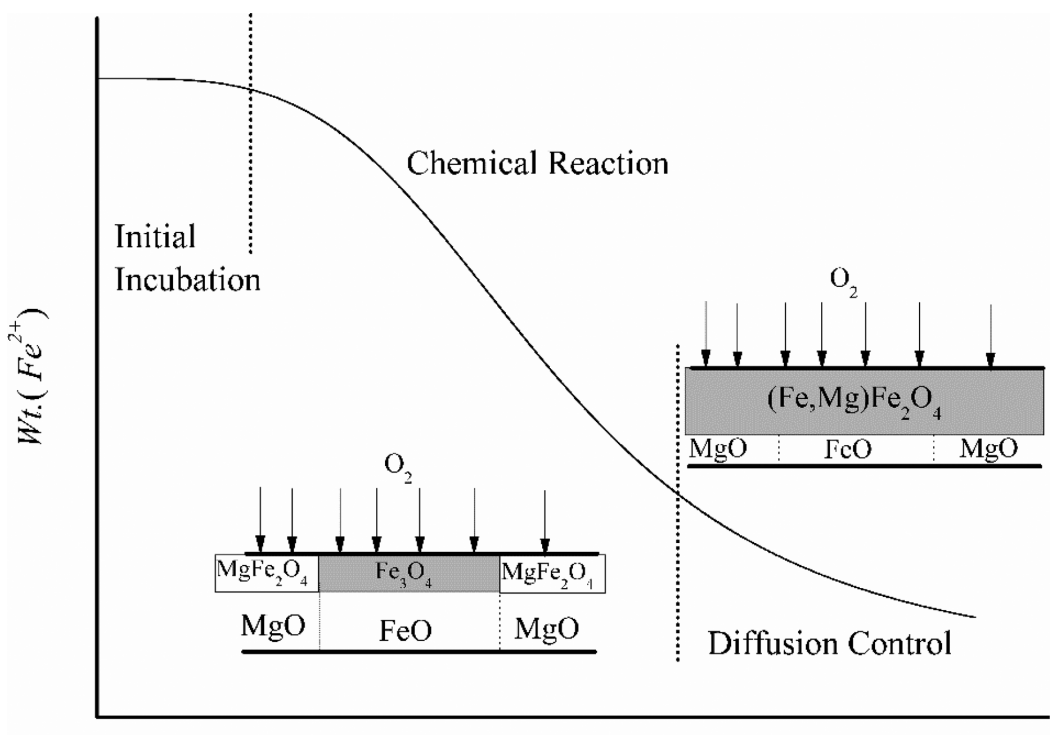

Time $(\mathrm{t})$

Figure 8: Illustration of the plausible steps in the oxidation mechanism.

temperature. According to eq. (4), the mean free path of the oxygen molecule is $1.48 \times 10^{-11} \mathrm{~m}$. The surface morphology of the modified slag at $1300^{\circ} \mathrm{C}$ is shown in Figure 9. The diameter of the pores obtained from the SEM micrograph was approximately $1-5 \times 10^{-6} \mathrm{~m}$. Thus, the pores are sufficiently large to ensure the diffusion of oxygen molecules during the oxidation process.

\section{Hydration heat evolution}

The rate of heat evolution of raw slag and oxidized slag is presented in Figure 10(a). The first peak of the curve corresponds to the rapid heat release period relating to the partial dissolution of slag [2]. For $\mathrm{S}_{\mathrm{R}}, \mathrm{S}_{\mathrm{O}-1250}, \mathrm{~S}_{\mathrm{O}-1300}$ and $\mathrm{S}_{\mathrm{O}-1350}$, the values of the first peak are $4.87 \mathrm{~mW} \mathrm{~g}^{-1}, 5.16 \mathrm{~mW} \mathrm{~g}^{-1}$, $6.41 \mathrm{~mW} \mathrm{~g}^{-1}, 8.29 \mathrm{~mW} \mathrm{~g}^{-1}$, respectively. Figure 10(b) shows the cumulative hydration heat evolution curves of raw slag and oxidized slag. The cumulative hydration heats of $S_{R}$, $\mathrm{S}_{\mathrm{O}-1250}, \mathrm{~S}_{\mathrm{O}-1300}$ and $\mathrm{S}_{\mathrm{O}-1350}$ are $26.8 \mathrm{~J} \mathrm{~g}^{-1}, 24.8 \mathrm{~J} \mathrm{~g}^{-1}, 33.9 \mathrm{~J} \mathrm{~g}^{-1}$ and $37.3 \mathrm{~J} \mathrm{~g} \mathrm{~g}^{-1}$ after $72 \mathrm{~h}$, respectively. Except $\mathrm{S}_{\mathrm{O}-1250}, \mathrm{~S}_{\mathrm{O}-1300}$ and $\mathrm{S}_{\mathrm{O}-1350}$ exhibit better hydration than that of raw slag. The primary cementitious phase in investigated slag is $\mathrm{C}_{2} \mathrm{~S}$, meanwhile the presence of $\mathrm{C}_{2} \mathrm{~F}$ exhibits beneficial effect on the hydration of slag [46]. Slower cooling rates allow cementitious phases in slag to crystallize much better than those of oxidized slag under quenching process, thus the activity of raw slag is much lower.

\section{Conclusions}

(1) Thermodynamics analyses of the steel slag at different temperatures in air suggest the feasibility of
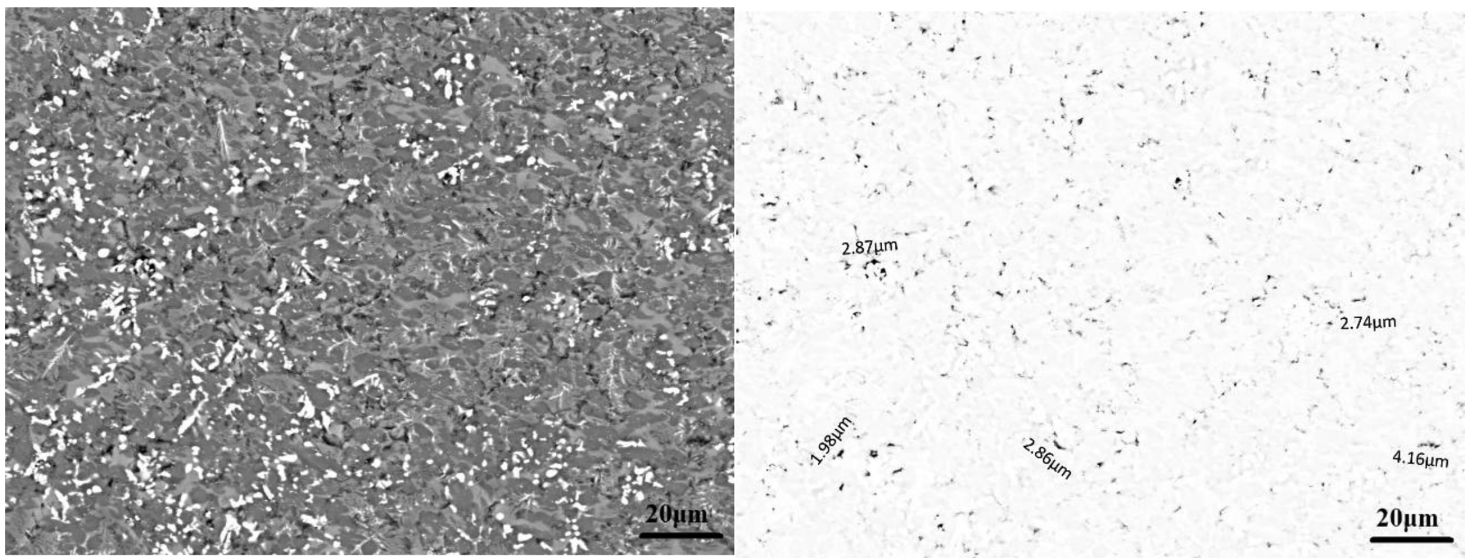

Figure 9: Surface morphology of the modified slag at $1300^{\circ} \mathrm{C}$. 

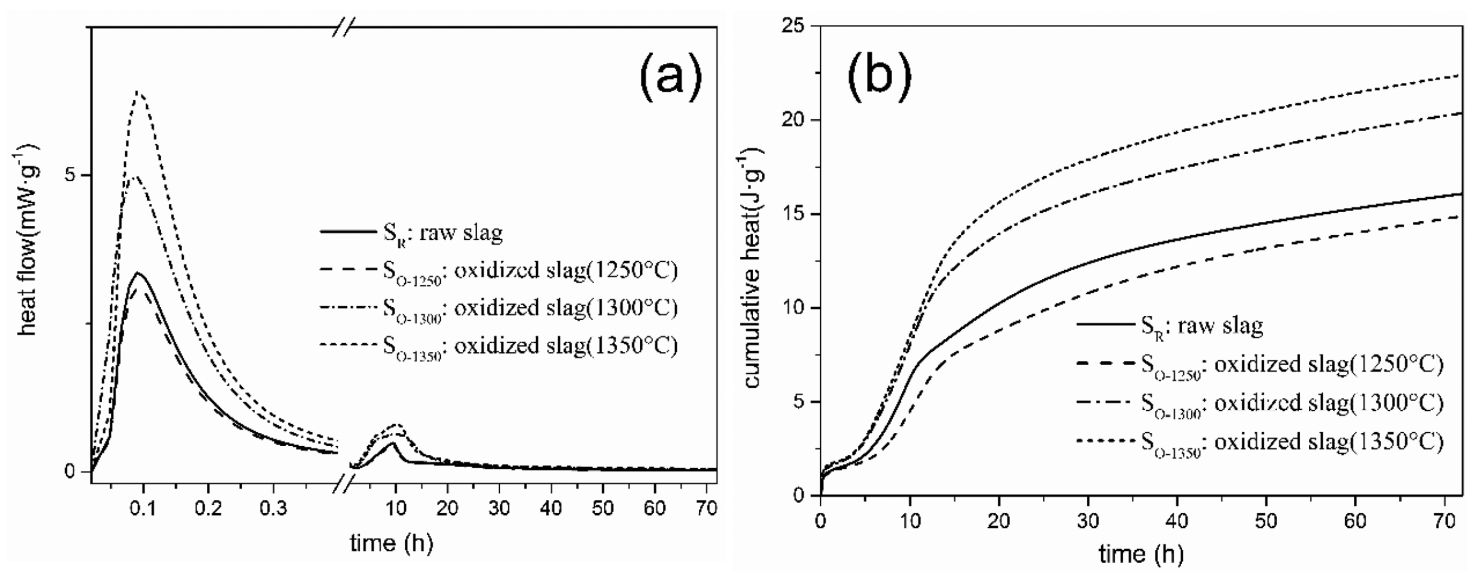

Figure 10: Hydration heat evolution of the raw slag and the oxidized slag: (a) rate of heat evolution of the raw slag and the oxidized slag; and (b) cumulative heat of the raw slag and the oxidized slag.

transforming the non-magnetic constituent of wustite to magnetic magnetite and magnesioferrite. The XRD, SEM and EDS analyses of the modified slag confirm the formation of magnetic phases.

(2) Temperature appears to have pronounced influence on the formation of magnetite, magnesioferrite and hematite. Hematite becomes unstable and begins to dissociate to form magnetite with a heating temperature above $1250^{\circ} \mathrm{C}$. As the temperature continues to rise, the mass fraction of spinel begins to decrease due to the formation of a liquid phase.

(3) The mass fraction of free lime is significantly reduced by the oxidation process. Free lime transforms into stable dicalcium ferrite, whereas periclase converts into magnesioferrite. The mass fraction of free lime decreased from $3.54 \mathrm{wt} . \%$ to $0.96 \mathrm{wt} . \%$, which was attributed to the formation of dicalcium ferrite.

Acknowledgements: This research work was funded by the Project 5 of Sweden CAMM2 (Centre of Advanced Mining and Metallurgy) Work Package 4, WP4 (1563365), the Ningxia State international cooperation program (Grant No. 2013ZYH187) and the Science and Technology Support Program of Ningxia province (2014ZYH50).

\section{References}

[1] H. Motz and J. Geiseler, Waste Manage., 21 (2001) 285-293.

[2] Q. Wang, P.Y. Yan and S. Han, Sci. China Tech. Sci., 54 (2011) 388-394.

[3] L.H. Zhao, W. Wei, H. Bai, X. Zhang and D.Q. Cang, Int. J. Miner. Metal. Mater., 22 (2015) 325-333.

[4] C.J. Shi, J. Mater. Civ Eng., 16 (2004) 230-236.
[5] L. Darken and R. Gurry, J. Am. Chem. Soc., 67 (1945) 1398-1412.

[6] I.M. Asi, H.Y. Qasrawi and F.I. Shalabi, Can. J. Civil Eng., 34 (2007) 902-911.

[7] S.P. Wu, Y.J. Xue, Q.S. Ye and Y.C. Chen, Build. Environ., 42 (2007) 2580-2585.

[8] Y.W. Dong, Z.H. Jiang, Y.L. Cao, H.K. Zhang and H.J. Shen, J. Cent. South Univ., 21 (2014) 4104-4108.

[9] A. Semykina, V. Shatokha and S. Seetharaman, Ironmak. Steelmak., 37 (2013) 536-540.

[10] S. Jung and Y. Do, Steel Res. Int., 77 (2006) 312-316.

[11] S. Jung, Y. Do and J. Choi, Steel Res. Int., 77 (2006) 305-311.

[12] H. Alanyali, M. Çöl, M. Yilmaz and Ş. Karagöz, Waste Manage., 26 (2006) 1133-1139.

[13] K. Yokoyama, H. Kubo, K. Mori, H. Okada, S. Takeuchi and T. Nagasaka, ISIJ Int., 47 (2007) 1541-1548.

[14] D.Y. Wang, M.F. Jiang, C.J. Liu, Y. Min, Y.Y. Cui, J. Liu and Y.C. Zhang, Steel Res. Int., 83 (2012) 189-196.

[15] L.N. Zhang, L. Zhang, M.Y. Wang and Z.T. Sui, Trans. Nonferrous Met. Soc. China, 15 (2005) 938-943.

[16] A. Semykina, V. Shatokha, M. Iwase and S. Seetharaman, Metall. Mater. Trans. B, 41 (2010) 1230-1239.

[17] A. Semykina, Metall. Mater. Trans. B, 43 (2012) 56-63.

[18] A. Semykina, J. Nakano, S. Sridhar, V. Shatokha and S. Seetharaman, Metall. Mater. Trans. B, 41 (2010) 940-945.

[19] H.J. Zhao, Q.J. Yu, J.X. Wei, J.X. Li and C.X. Gong, J. Wuhan Univ. Technol., 32 (2010) 22-26.

[20] D.X. Li, X.H. Fu, X.Q. Wu and M.S. Tang, Cem. Concr. Res., 27 (1997) 983-987.

[21] G.R. Qian, D.D. Sun, J.H. Tay, Z.Y. Lai and G.L. Xu, Cem. Concr. Res., 32 (2002) 1377-1382.

[22] C.J. Shi and S.F. Hu, Cem. Concr. Res., 33 (2003) 1851-1856.

[23] Y.M. Chen and H.T. Zhang, Cem. Chin., 5 (2001) 1-4.

[24] Z.B. Li, S.Y. Zhao, X.G. Zhao, T.S. He and M.F. Yan, Mater. Struct., 46 (2013) 327-336.

[25] L. Jiang, Y.W. Bao, Y.H. Chen and Q.X. Yang, Mater. Rev., 32 (2017) 650-671.

[26] L. Jiang, Y.W. Bao, Q.X. Yang and Y.H. Chen, Steel Res. Int., 88 (2017) 1-12.

[27] Y.J. Wang and G.X. Ye, J. Chin. Silic. Soc., 9 (1981) 302-308. 
[28] J. Geiseler, Waste Manage., 16 (1996) 59-63.

[29] E. Belhadj, C. Diliberto and A. Lecomte, Cem. Concr. Compos., 34 (2012) 34-40.

[30] J.X. Li, Q.J. Yu, J.X. Wei and T.S. Zhang, Cem. Concr. Res., 41 (2011) 324-329.

[31] B. Wang, J. Beijing Univ. Chem. Technol., 38 (2011) 17-21.

[32] A.S. Reddy, R. Pradhan and S. Chandra, Int. J. Miner. Process., 79 (2006) 98-105.

[33] S. Panigrahy, P. Verstraeten and J. Dilewijns, Metall. Trans. B, 15 (1984) 23-32.

[34] L. Blackman, J. Am. Ceram. Soc., 42 (1959) 143-145.

[35] B. Phillips and A. Muan, J. Am. Ceram. Soc., 41 (1958) 445-454.

[36] U. Yadav, B. Pandey, B. Das and D. Jena, Ironmak. Steelmak., 29 (2002) 91-95.

[37] P. Xue, D.F. He, A.J. Xu, Z.X. Gu, Q.X. Yang, E. Fredrik and B. Bo, J. Alloys. Compd., 712 (2017) 640-648.
[38] Q.F. Shu and Y. Liu, Ironmak. Steelmak., 45(2018): 363-370.

[39] U. Yadav, B. Pandey, B. Das and D. Jena, Ironmak. Steelmak., 29 (2013) 91-95.

[40] F.M. Lea, The Chemistry of Cement and Concrete, Edward Arnold Publishers Limited, London, UK (1970).

[41] G. Wirtz and M. Fine, J. Appl. Phys., 38 (1967) 3729-3737.

[42] B.F. Bohor, E.E. Foord and R. Ganapathy, Earth Planet. Sci. Lett., 81 (1986) 57-66.

[43] G.H. Hou, W.F. Li, W. Guo, J.H. Chen, J.H. Luo and J.G. Wang, J. Chin. Ceram. Soc., 36 (2008) 436.

[44] H.M. Ahmed, A. Persson, L.S. Okvist and B. Bjorkman, ISIJ Int., 55 (2015) 2082-2089.

[45] J.N. Murphy, T.R. Meadowcroft and P.V. Barr, Can. Metall. Q., 36 (2013) 315-331.

[46] Z.B. Li, S.Y. Zhao, X.G. Zhao and T.S. He, Constr. Build. Mater., 48 (2013) 575-579. 